\title{
An aspect of Neolithisation in Mongolia: the Mesolithic-Neolithic site of Tamsagbulag (Dornod district)
}

\author{
Michel Louis Séfériadès \\ UMR 6566, CNRS, Universités Rennes 1, Laboratoire d'Anthropologie, \\ Rennes et Nantes, France \\ michel.seferiades@univ-rennes1.fr
}

\begin{abstract}
The article outlines the first results of the French Archaeological Mission to Mongolia centered on the Neolithic. The topics discussed include general aspects of the initial Neolithisation in Eurasia, and the use of state-of-the art archaeological techniques in studies of Prehistory, with special reference to the Mesolithic/Neolithic interface, as exemplified by a survey and excavations in the area of Tamsagbulag site (Eastern Mongolia, aimak/district of Dornod) originally investigated by a Soviet-Mongolian mission directed by Professor A. P. Okladnikov, a renowned Russian archaeologist.

IZVLEČEK - V članku orišemo prve rezultate francoske arheološke misije v Mongolijo, ki se je osredotočila na neolitik. Obravnavamo splošne vidike začetne neolitizacije v Evraziji in uporabo najboljših arheoloških tehnik pri raziskavah prazgodovine, posebno v zvezi z razmejitvijo mezolitika in neolitika. To ponazorimo s terenskim pregledom in izkopavanji na območju najdišč Tamsagbulag (vzhodna Mongolia, aimak/okrožje Dornod), ki ga je prvotno raziskala rusko-mongolska odprava pod vodstvom profesorja A. P. Okladnikova, slovitega ruskega arheologa.
\end{abstract}

KEY WORDS - Mongolia; Tamsagbulag surveys and excavations; Neolithisation; Mesolithic; Neolithic

\section{INTRODUCTION}

I would like to discuss here the project of the French Archaeological Mission in Mongolia for the Neolithic Period. This project covers Outer Mongolia, half way between Russia (Siberia) to the north, Kazakhstan to the west and China (Inner Mongolia and Manchuria), Korea and Japan to the south and east (Map 1).

Despite the fact that more than a thousand Paleolithic sites are recorded and that the period is relatively well known there, this was not the case of the Neolithic (a fortiori for the Mesolithic) (Map 2). In the words of my colleague and friend Professor Jacques Legrand (INALCO, Paris): "Research into the Neolithic of Mongolia should provide informations and essential hypotheses which would improve our knowledge of the rise and formation of Central Asiatic nomadic pastoralism (particularly Mongolian), a phenomenon which dominated the historic period throughout the central and eastern part of Eurasia." At the beginning and concurrently with the NorthPontic and Danubian areas, waves of nomadic pastoralists (Proto-Indo-Europeans in the opinion of many of my colleagues) disrupted the established economic and social structures of the sedentary Neolithic and Eneolithic groups (the Cucuteni-Tripolye, Gumelnitsa, Karanovo VI, etc.), introducing, among other novelties, the horse and wheel.

Amazingly, more is known of dinosaurs' fossil eggs and bones in the Gobi Desert than of the Neolithic of Mongolia. But despite the paucity of publications, there is a fair amount of actual data available. At the Department of Archaeology of the Institute of History at Ulaan Baatar, with the help of my Mongolian colleague B. Gunchinsuren, I started a personal inventory of Mesolithic and Neolithic sites, putting 


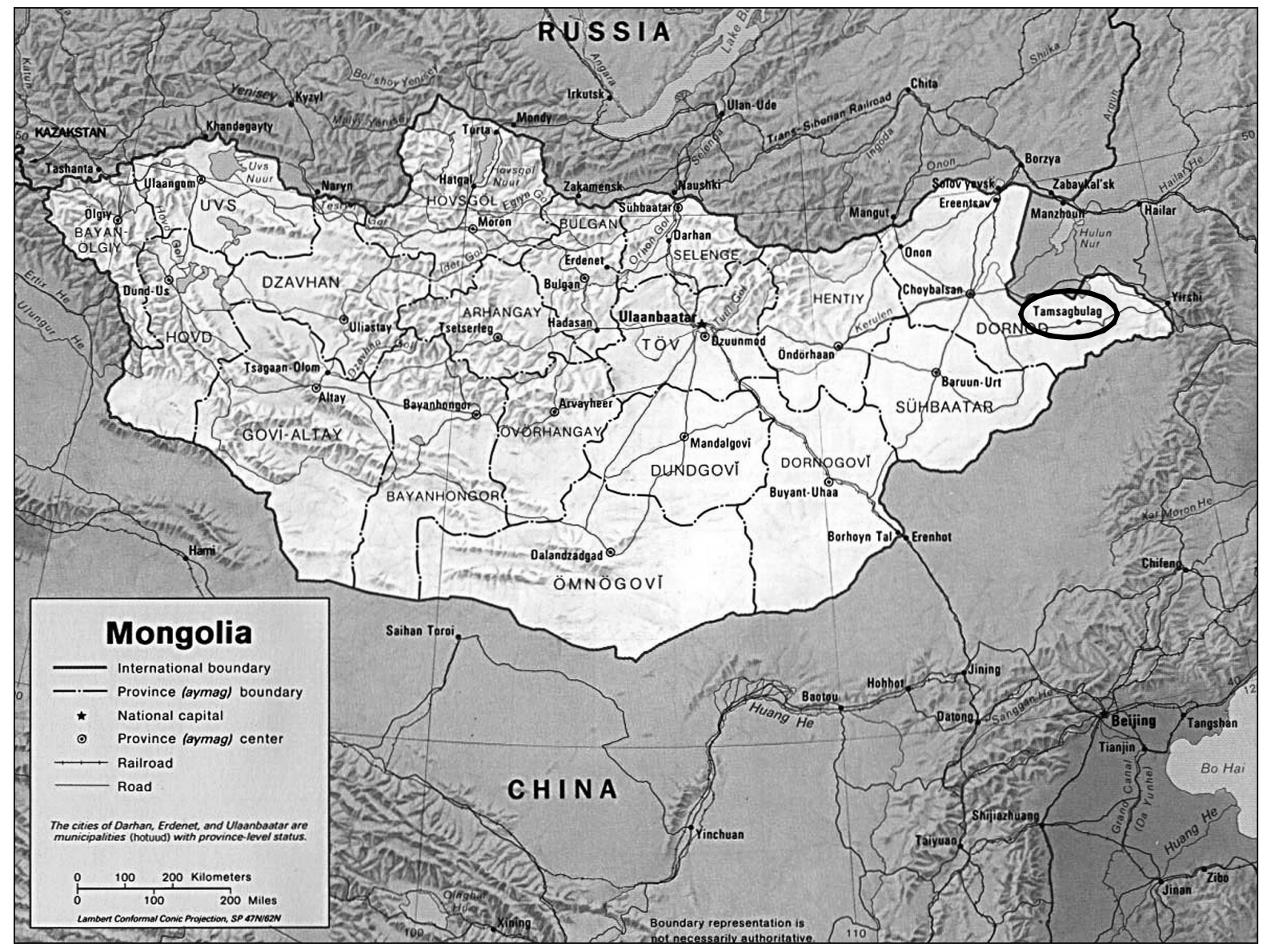

Map 1. Location of Tamsagbulag (Dornod aimak/district of Eastern Mongolia).

them on the map. I also started to study the stone tools and ceramic assemblages, primarily from unpublished and poorly known Soviet and Mongolian surveys and excavations.

On this basis, I identified four regions of Mesolithic and Neolithic socio-economic and cultural entities: (1) The region west of the Altai and west of the Khangai Mountains.

(2) The north-central region south of Lake Baikal.

3 The southern region of northern of China (the Northern Gobi).

(4) The eastern region of north and western Manchuria.

Yet this pattern results rather from the state of our knowledge than a carefully designed research strategy. It is mainly based on surface finds (stone tools, sherds, etc.). Results from systematic excavations are few, especially in chronostratigraphic sequences. The only excavation worthy of the name is that of the Soviet Mission directed (first in 1949 and then 1967) by the renowned Russian archaeologist A. P. Okladnikov at the Mesolithic/Neolithic site of Tamsagbulag (eastern Mongolia, Dornod aimak).
THE FRENCH ARCHAEOLOGICAL MISSION IN MONGOLIA FOR THE NEOLITHIC PERIOD

The French Archaeological Mission in Mongolia for the Neolithic Period was established in 1996 under the auspices of the French Foreign Office and the Mongolian Academy of Sciences (Institute of History), with the intention, as its first objective, of undertaking remote sensing, excavations, and surveys at Tamsagbulag. Despite the brevity of reports on earlier Soviet excavations (essentially by Okladnikov, Derevianko 1970; Dorj 1971), it became clear that this was a key Mesolithic/Neolithic site in Central Asia, and this was confirmed by both the materials from these excavations and by two recent syntheses by A. P. Derevianko and D. Dorj (1992) and A. P. Derevianko (1994).

Tamsagbulag is the key site for the Tamsagbulag Culture, which, in my opinion (see below), dates to the $5^{\text {th }}$ millenium BC. The occupants were both sedentary hunter-fisher-gatherers and farmers. Semi-subterranean dwellings (with posts supporting the roof) oriented south-east to north-west (around $40 \mathrm{~m}^{2}$ : $7.60 \mathrm{~m}$ long, $5.60 \mathrm{~m}$ wide and $0.60 \mathrm{~m}$ deep), with 
Map 2. Most important Neolithic sites in central and northern Asia (after A. P. Der evianko 1994): 1. Yamat Nuur, 2. Ovoot, 3. Tamsagbulag, 4. Khuitynbulag, 5. Shabarak, 6. Daringanga, 7. Arshan-Khad, 8. Chandman, 9. Uldzit, 10. Andreyevskoe lake, 11. Chestyi-yaga, 12. the Samus burials, 13. the Tomsk burials, 14. Alexandrovskoe, 15. Zavjalovo, 16. Ust-Khemchik, 17. Toorakhem, 18. Khadynnykh, 19. Kuyum, 20. the Vaskovskoe burial, 21. the Tomsk petroglyphs, 22. Lenkovka, 23. the Chastaya and Khinskaya valleys, 24. Olkhon, 25. Kamennye isles, 26. Mukhinskoe, 27. Chindant, 28. Budulan,

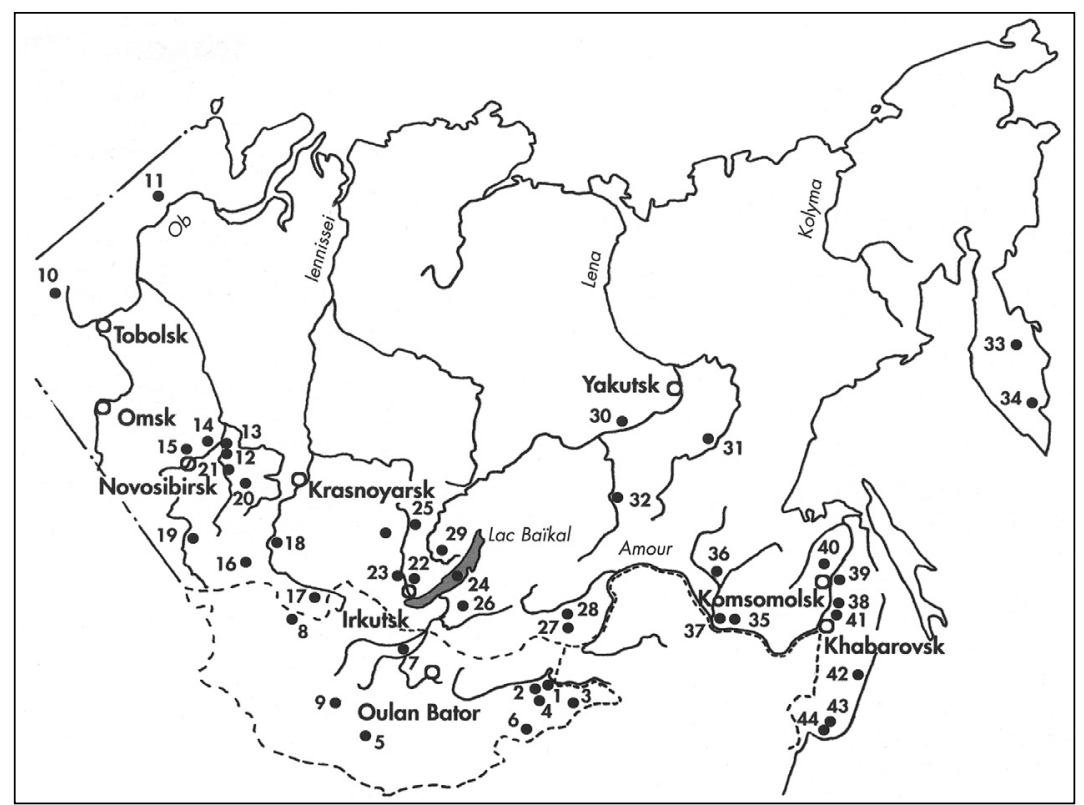

29. Shishkino, 30. Kullaty, 31. Belkachi, 32. Krestyakh, 33. Ushkovskaya, 34. Tarya, 35. Novopetrovka, 36. Gromatukha, 37. Osinovoe lake, 38. Malyshevo, 39. Voznesenska, 40. Kondon, 41. Sakachi-Alyan, 42. Rudnaya, 43. Zaisanovska, 44. Kirovskoe.

storage pits and burials inside the houses were found. The stone (chipped and polished) and bone tool assemblages, and ceramic materials are rich, as are the paleobotanical and faunal samples (millet, large fish, bird, cattle, pig, horse, etc.). A bull cult inherited from Paleolithic times (see Séfériadès and Stanko 2000) has been identified from a pit filled with the bones of this animal.

\section{THE 1997 FIELD SEASON}

Tamsagbulag ("bulag" meaning "spring" in Mongolian) lies south-east of the town of Choibalsan, in the desert-steppe region just a few kilometers from the Chinese border (Manchuria), a region that was abundant in black-tailed gazelles and saiga antelopes before (so people say) the Soviet Army finished them off. It forms part of a large lake, which today is almost completely dry, one-two kilometres wide between the higher southern terraces (Tamsagbulag 1) and the lower northern ones (Tamsagbulag 2). In the north, we were able to locate the remains of the village of Tamsagbulag, built of mud-bricks and abandoned some fifty years ago (?). A few kilometres to the North-East one may note a series of small lakes located south of the larger Lake Buir.

\section{Tamsagbulag 1}

With some difficulty we are able to locate the site of Tamsagbulag 1 on the basis of its position in rela- tion to a cliff ten-twelve metres high with a spring at its foot, mentioned in a brief publication of A. P. Okladnikov and A. P. Derevianko.

It seems possible that Mesolithic and Neolithic hunters of gazelle and antelope were based here in much the same way as Magdalenian hunters awaited reindeer on the left bank of the Seine at Pincevent; and during the Late Upper Paleolithic, on the Bug terrace in Ukraine, bison herds were taken at Anetovka more than ten thousands years ago (Séfériadès and Stanko 2000).

During the first campaign (August/September 1997), two complementary strategies were adopted:

(1) Intensive surveys yielded several hundred stone tools, including several polished ones, and a significant number of potsherds suggesting an affinity with the Neolithic of the Lake Baikal and Amur region of Siberia and contemporary groups in southeast Asia. (2) Four trenches (A, B, C and D) from 1 to $4 \mathrm{~m}^{2}$ in size were dug:

Trench $\boldsymbol{A}\left(4 \mathrm{~m}^{2}\right)$ on the higher terrace, a few metres from the cliff facing the spring yielded no archaeological material, but provided excellent stratigraphy for sedimentological and palynological analyses (Fig. 1). Two stratigraphic exposures to the eastwest and north-south provided a sequence for the upper terrace occupied during the Neolithic: below the vegetal topsoil $(20 \mathrm{~cm})$ there was a sequence of sand $(90 \mathrm{~cm})$ resting on compact clayey soil. The latter caused us to stop the excavations. The stratigra- 
phy provided information on the formation of the upper terrace, the palaeoclimate, the landscape, and biotopes and ecosystems of semi-sedentary Mesolithic/Neolithic groups at the beginning of the Holocene.

Trenches $B$ and $C$ were located two hundreds metres south of the spring. Only trench B yielded chipped stone artefacts (Neolithic).

Trench D $\left(3 \mathrm{~m}^{2}\right)$ at the foot of the terrace, not far from the spring, yielded the upper part of the brown and yellow Neolithic layer mixed with charcoal and ash (with chipped stone tools, fragments of pottery). A ${ }^{14} \mathrm{C}$ date from this trench (Gif. 10949) of $5590 \pm 120 \mathrm{BP}$ (cal 4753$4155 \mathrm{BC}$ ) was obtained. This date is of the same order as the dates for Neolithic sites obtained in China.

\section{Tamsagbulag 2}

Tamsagbulag 2 is a new site, discovered on the opposite (northern) bank of the ancient lake. There, over one hundred metres on both sides of the remains of the "Soviet Army bridge", a brief investigation yielded chipped stone artefacts and ceramic assemblages which belong predominantly to historic times. A few metres to the west of the military bridge, the remains of a Tibetan monastery (?), a temple, and a sort of clay hearth with numerous vases and other cultural objects were found.

\section{Tamsagbulag 3}

Tamsagbulag is yet another new site, discovered on the eastern side of the ancient lake; it lies to the

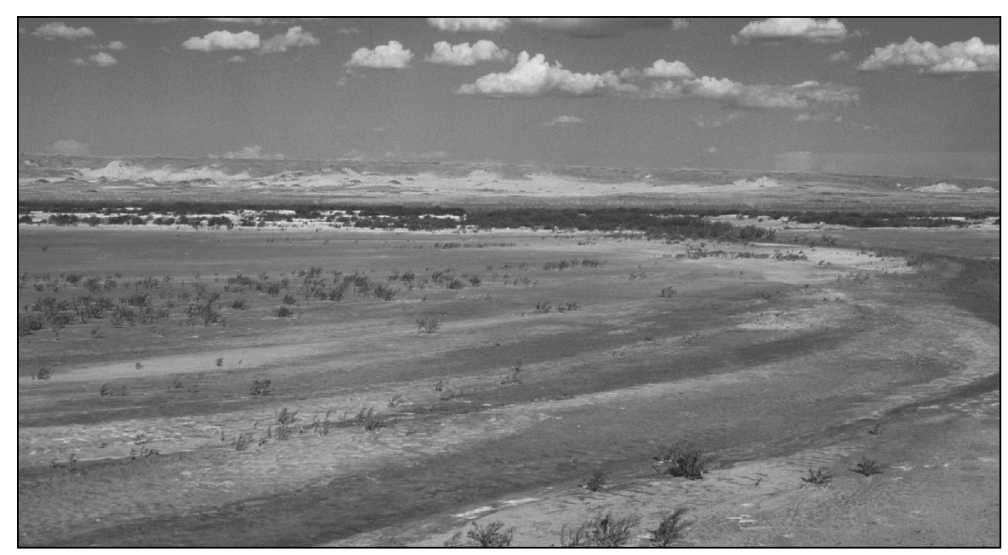

Fig. 2. Tamsagbulag 3. The Mesolithic/Neolithic site (palaeo-shorelines) discovered in 1997 during the first mission. north- north-east of Tamsagbulag 1 (Fig. 2). A small lake, almost completely dried up to-day, is surrounded by small sand dunes. Intensive reconnaissance on the eastern bank of the lake, below the small terrace and on the gentle (windward) slope of the dune, has yielded important lithic and ceramic materials. The artefacts collected came from a Neolithic camp or habitation site located not far from the terrace. The chipped stone industry and sherds were concentrated at the foot of the terrace.

In the areas of a dense concentration of lithics and pottery, a long bone of gazelle or antelope (which appeared to be a fossil, given the state of preservation) was recovered. The ${ }^{14} \mathrm{C}$ date obtained places the site in the third millenium $\mathrm{BC}$ - more recent than Tamsagbulag 1. Presumably, groups of Mesolithic hunters who became more sedentary in the process of Neolithisation, moved from the large dried-out lake area of Tamsgbulag 1 of the fifth millenium, to the residual lake of Tamsagbulag 3 in the third millenium, prior to having to opt once again for a nomadic way of life - this time definitively.

\section{ARCHAEOLOGICAL MATERIAL}

\section{Chipped stone industry}

The several hundreds of pieces recovered suggest the occurence of a rich assemblage. Raw materials consist of local flint (opaque and translucent) and semi-precious stones of various 
Fig. 3. Tamsagbulag 1. Microlithic industry: Nucleus.

colours (chalcedony, quartz, crystal, jasper, etc.). The microlithic industry dominates the secondarychipped lithics. Small

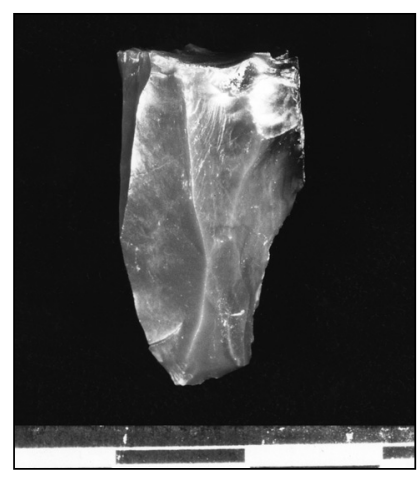
lake pebbles are notable, and are being analysed. One should note: prismatic nuclei, pyramidal nuclei, sub-pyramidal nuclei, bladelet nuclei (Fig. 3), the products of pressure flaking, standardised production using homogeneous raw material, morphologically varied blades and bladelets (for example, sickle microblades inserted into knives) (Fig. 4), blade

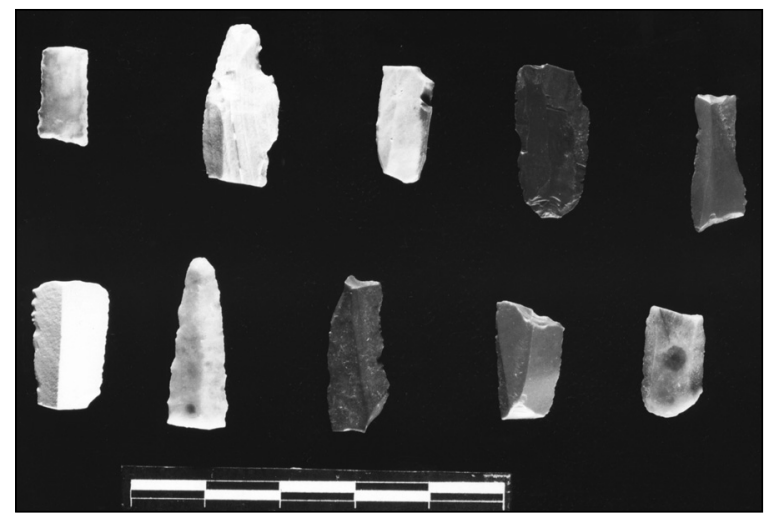

Fig. 4. Tamsagbulag 1. Microlithic industry: bladelets.

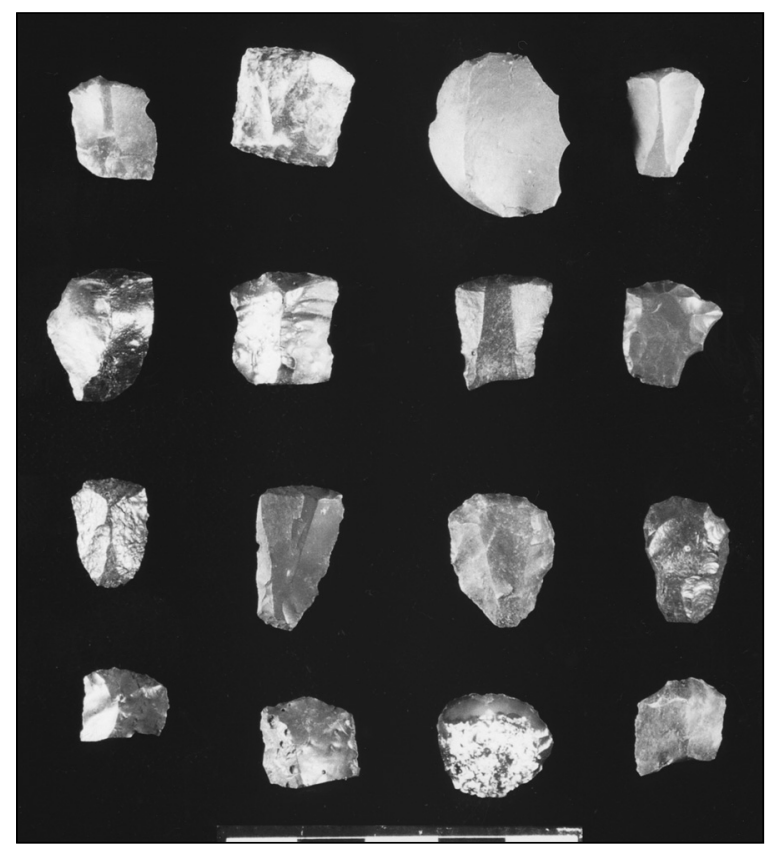

Fig. 5. Tamsagbulag 1. Thumbnail (micro)scrapers. scrapers, thick endscrapers carinated endscrapers, thumbnail (micro)scrapers (Fig. 5) and Tamsagbulag scrapers (Fig. 6), first recognised by A. P. Okladnikov (small plaquettes or fragments thereof of different shapes. Their edges are abruptly retouched). Burins and piercers are also present. A unifacially flaked leaf point in black stone (phtanite) (Fig. 7) and quartz arrow-heads come from Tamsagbulag 1. Typical microliths (geometric) seem absent.

\section{Polished stone industry}

Only five pieces have been recovered: an axe or adze fragment, a pestle fragment, fragments of a large disc and a heavy perforated circular tool (for digging sticks?) in volcanic rock from Tamsagbulag 3 (Fig. 8). A. P. Okladnikov's excavations yielded a similar piece and millstones also in volcanic rock.

\section{Bone industry}

No bone tools werefound among the surface collection, but knives, dagger knives, or sickles (stone bladelets mounted in a bone haft) (Fig. 9) are well represented in A. P. Okladnikov's excavation assemblages as items of jewellery (beads) (Fig. 10).

\section{Ceramics}

The surveys and excavations at Tamsagbulag 1, 2 and 3 have yielded fragments of Neolithic and Early (?) Bronze Age pottery. Neolithic/EBA sherds are distinguished by their friable raw material, with a high content of sand (and shell?) and grey surface, incised or impressed surfaces (also corded ware), with elementary geometrical motifs, some of which look like pottery from southern Siberia, the Amur valley, northwestern China, Inner Mongolia and Manchuria, Korea, and southeastern Asia (Fig. 11). The discs

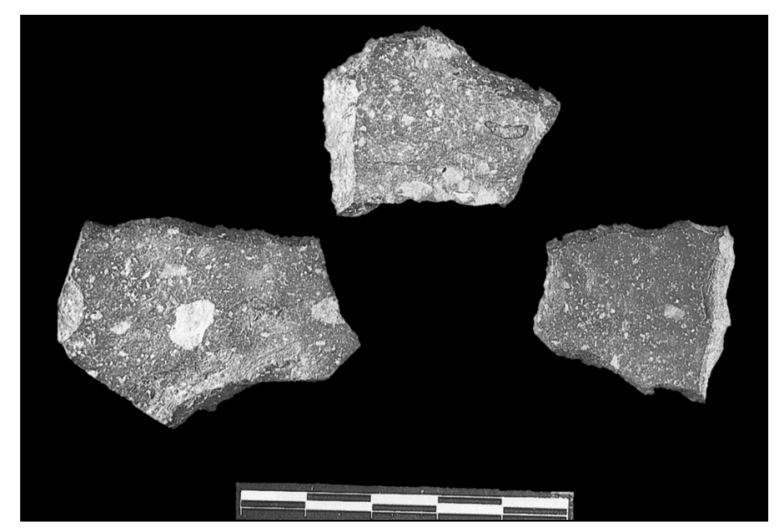

Fig. 6. Tamsagbulag 1. Tamsagbulag-type scrapers (small plaquettes with abruptly retouched edges). 


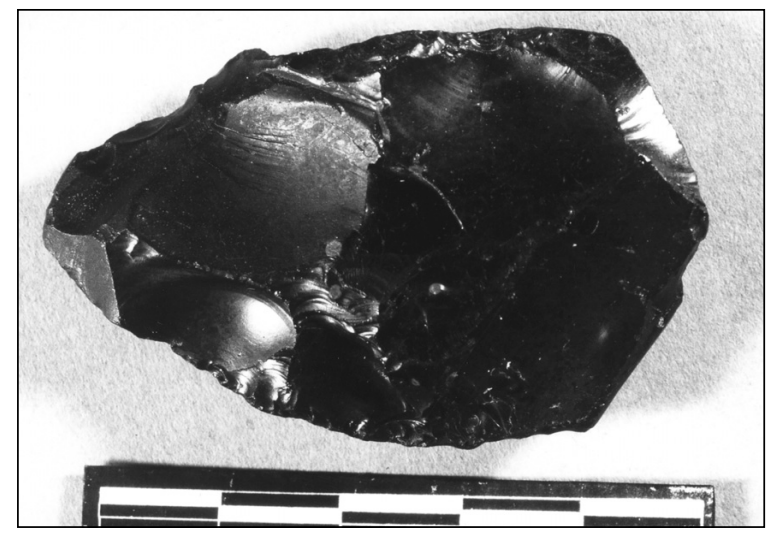

Fig. 7. Tamsagbulag 1. Unifacially flaked leaf point in black rock (phtanite).

were probably used for cereal pancakes or bread cooking (Fig. 12).

Metallurgy

Metallurgy is represented by bronze and iron objects and fragments which are dated to the Iron Age and modern period.

\section{Long-distance exchange}

Two pieces of obsidian, the millstone and the "brisemottes" of volcanic tuffaceous rock, also fragments of jade (?) and several sherds of decorated pottery indicate the occurrence of medium- and long-distance exchange network patterns. One should also note a pendant (exhibited in the Museum of Ulaan Baatar) from one of the burials excavated by A. P. Okladnikov (?), presumably lapis lazuli of Afghan origin.

\section{TAMSAGBULAG DEATH}

A. P. Okladnikov (Okladnikov and Derevianko 1970) reported burials found under house floors, with a series of grave goods (bone knives with inserted stone bladelets, necklaces of Maral incisors, and bone or mother of pearl beads (Unio), etc.) (Figs. 9

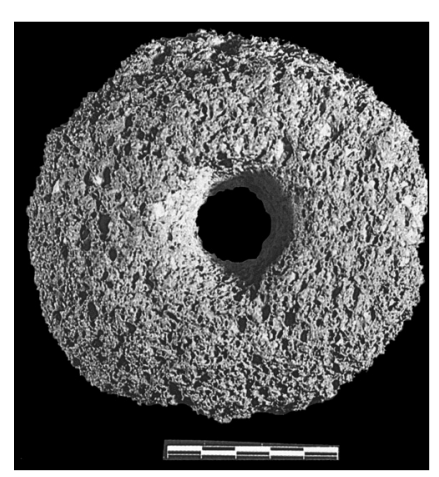
and 10). Remarkably, the skeletons were found in a sitting position! (Fig.

Fig. 8. Tamsagbulag 3. Perforated circular tool (for digging sticks?) in volcanic rock.
13). Unusual similarities with the mummies of Ancient Peru (Chachapoyas, Chancay, Paracas, etc.) come to mind. Flexed and sitting positions are unknown anywhere, and especially in Europe, West, Central and South-East Asia. They may suggest an emigration through the Bering Strait from the primary Eurasian area (Mongolia and northeastern Siberia) to the Americas (Alaska and the North American east coast) and then south to Central and South Americas.

\section{FIRST CONCLUSIONS}

The study of the site and its surroundings is indicative of a particular eco-system. Our field observations were corroborated by an analysis of satellite imagery (Landsat TM). E. Fouache, geomorphologist, points out (1998) that the terrain consists of a huge plateau at an altitude of $700 \mathrm{~m}$, with two large

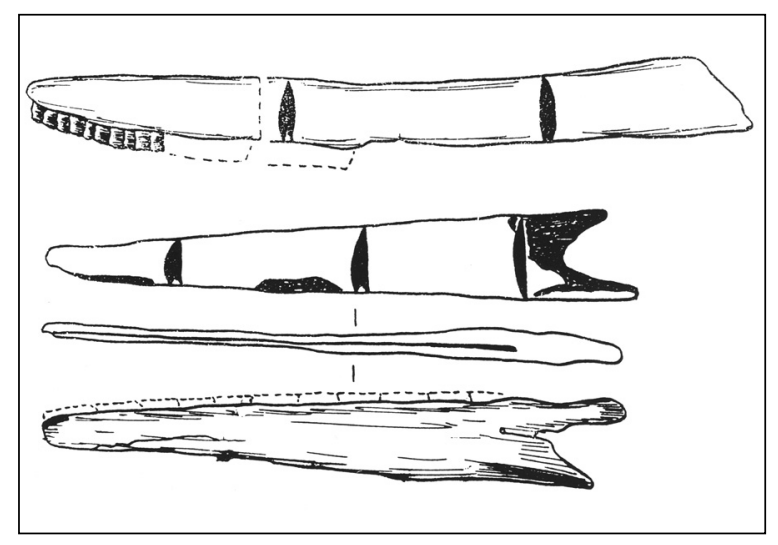

Fig. 9. Bone industry (knives, dagger knives or sickles) (after Dorj 1974).

depressions, one in the North, with Lake Buir, and another in the south, with a string of small lakes. The Neogene sediments form the base of the plateau, the Quaternary deposits filling in the depressions. Satellite imagery shows that the present-day lakes were interconnected (certainly at the beginning of the Holocene) by what is today a dry valley. Landsat images show clearly at Tamsagbulag a system of palaeo-shorelines indicative of a regression of the lake, which was never deeper than $12 \mathrm{~m}$ (Fig. 14). Intensive evaporation in this dry steppe environment was the likely cause of this regression. This site is highly appropriate for the study of Holocene climate fluctuations and their effects on the topography and human settlement.

The extension of the Palaeo-lakes forms a key element in the prospecting of Neolithic sites in this area 


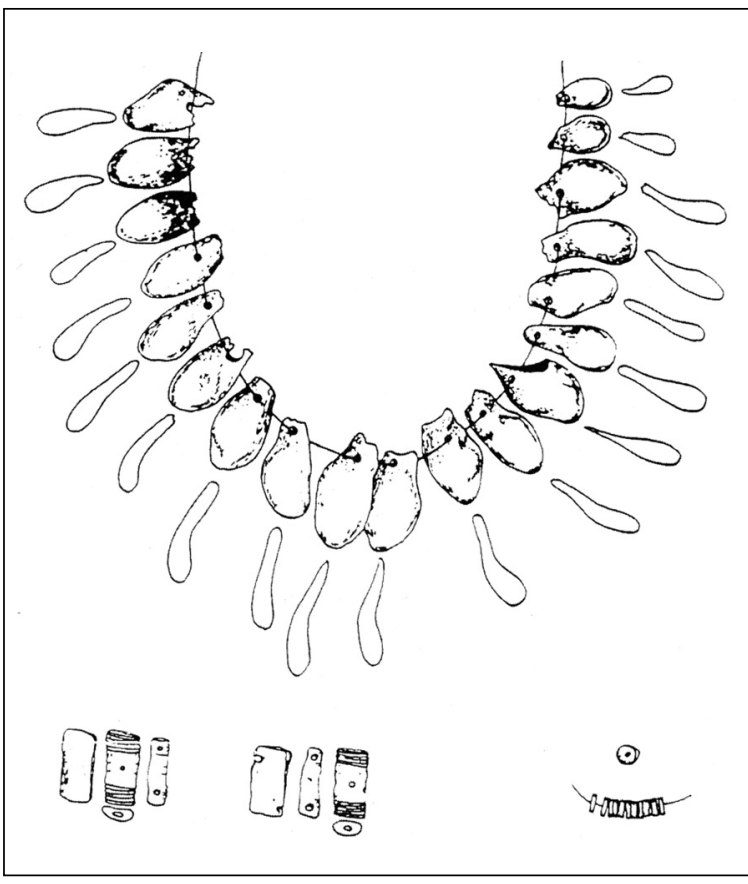

Fig. 10. Tamsagbulag 1. Necklace of stag canines, plate and tubular beads of pearl (Unio) from the graves (after Okladnikov and Derevianko 1970).

of the Dornod district (aimak) of Mongolia. Images taken during our first mission in 1997 clearly show that sites were closely associated with the former hydrological network. However, in the absence of a strict topographic control, the map shown here is only a first approximation of the disposition of rivers and lakes in the past.

It looks as if the Mesolithic-Neolithic inhabitants of Tamsagbulag and neighbouring sites existed in an

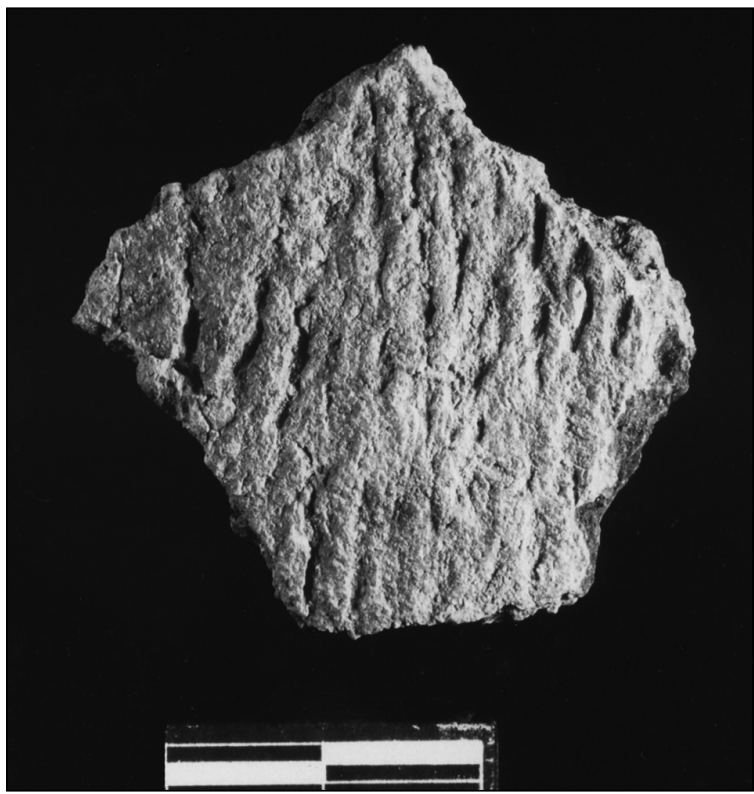

Fig. 11. Tamsagbulag 1. Corded ware.

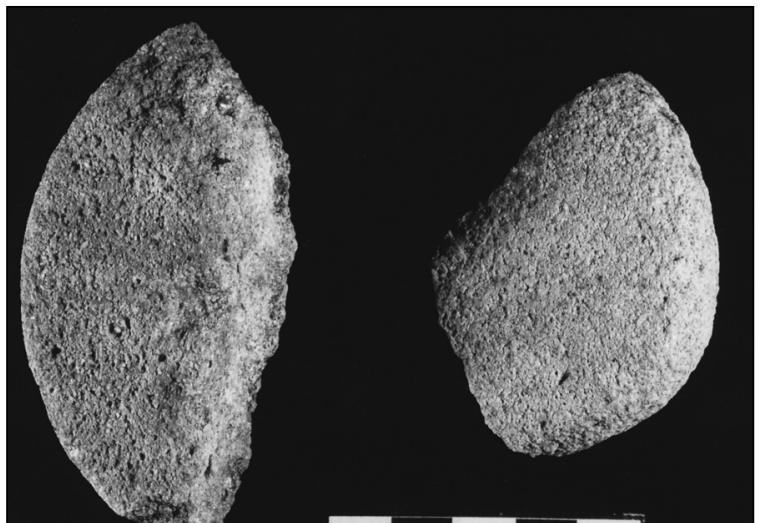

Fig. 12. Tamsagbulag 1. Fragments of discs allegedly used for cooking cereal pancakes or bread.

environment favouring partially predatory-type subsistence (hunting, fishing, and food-gathering), their biotope being equally proper for food-producing (domestication of plants and animals). The process of Neolithisation was well under way, highlighting a new type of sedentariness which accompanied the initial farming mode of subsistence in this part of eastern central Mongolia.

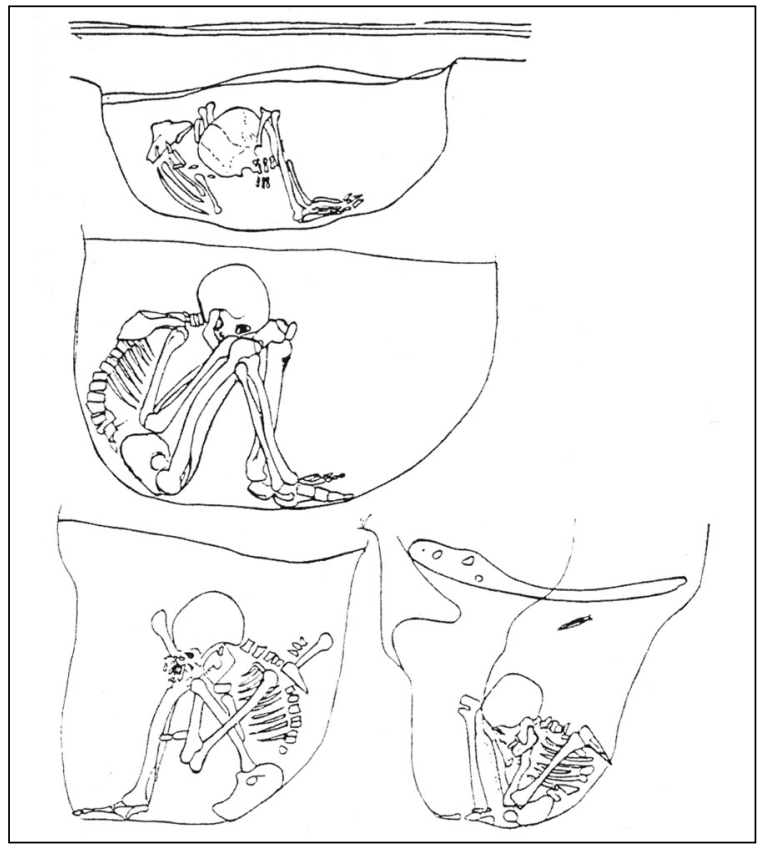

Fig. 13. Tamsagbulag 1. Types of graves discovered beneath the house floors (after OKladnikov and Derevianko 1970).

The presently monotonous steppe-desert looked quite different during the three millennia that began 7000 years ago. The climate then was mild and humid, the boundless grassland was abundant in marmot (tarbagan in Mongol), wolf and eagle; stag and boar thrived in the forests; small plots were located close to villages. Tamsagbulag consisted of se- 
Fig. 14. Analysis of satellite imagery (Landsat TM) by E. Fouache (University of Paris-Sorbonne 1998) showing a clear system of palaeo-shore-lines indicative of a regression of the lake during the Holocene.

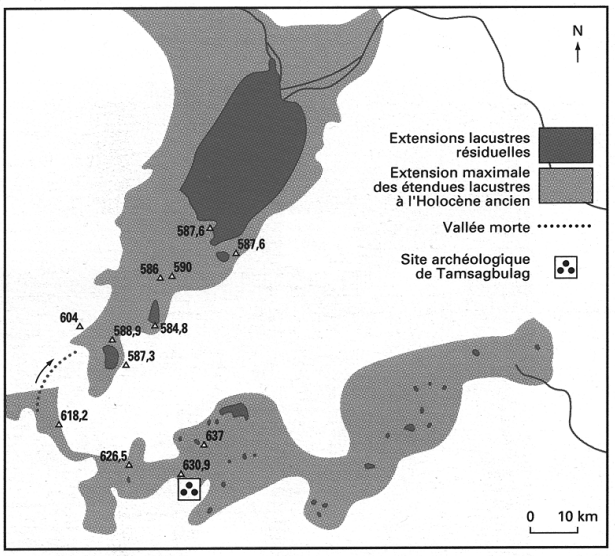

veral well-separated houses located on the border of the elevated terrace, near a spring, and stretching over a distance of $2-3 \mathrm{~km}$. From there, its inhabitants could observe the herds of wild animals roaming around the lake: black-tailed gazelle (xarsuult zeer), antelope saiga (boxon), and kulan (xulan). The hunters and fishers were direct heirs of their Mesolithic predecessors (arrows or spears with chipped stone or bone points; also harpoons with notches on one side). The local inhabitants were also

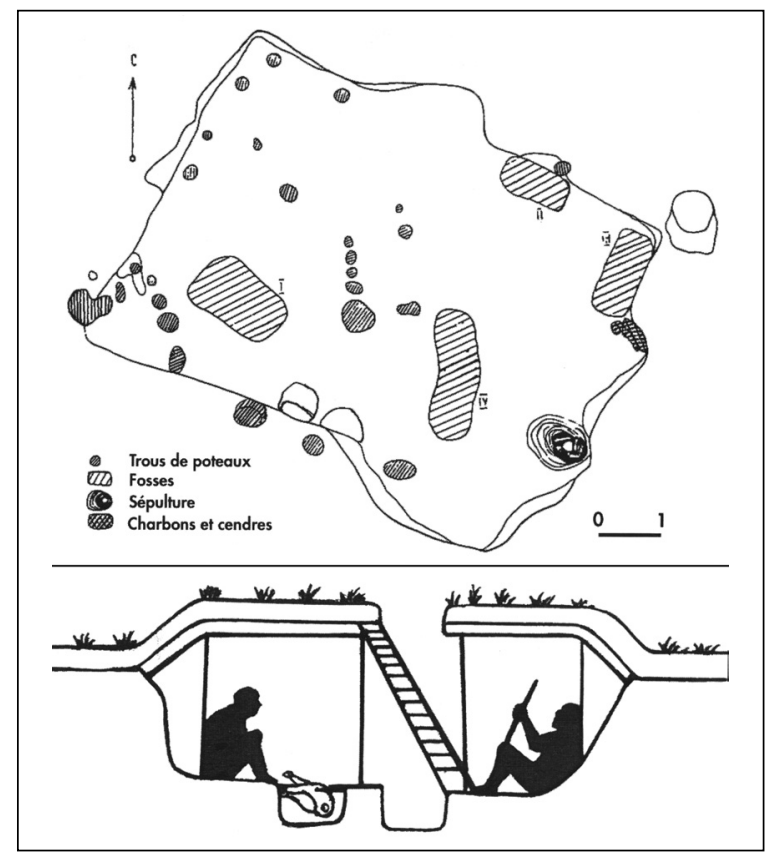

Fig. 15. Tamsagbulag 1. Plan of a semi-subterranean house (after Okladnikov and Derevianko 1970). farmers (they cultivated millet, likewise their counterparts in northern China), and stock-breeders, rearing cattle and, possibly horses (Okladnikov and Derevianko 1970).

Their rectangular wattle-and-daub semi-subterranean houses were $30-40 \mathrm{~m}^{2}$ in size (Okladnikov and Derevianko 1970) (Fig. 15). Wooden houses were also found similar to the winter dwellings used by the Ainou on the Kuril Islands in the early $20^{\text {th }}$ century. It seems that none of these houses had doors or windows, the only way of access being an aperture in the roof that was also used to remove the smoke, and stairs consisting of an inclined tree trunk with incised steps. Similar structures were used until recently in the winter dwellings of various peoples in Manchuria and Siberia, as well as the Koriaks in the Northern Pacific. For these peoples, as well as for those of Alaska reported by Cook in the course of his third journey two centuries ago, such stairs had sacred connotations, and were viewed as the guardians of the house (Figs. 16 and 17).

Both Soviet-Mongolian digs and our own investigations have yielded a rich archaeological assemblage that sheds light on early communities in Central Asia, who were hunters, fishers, and food gatherers, and, at the same time, sedentary farmers and stock-breeders.

Seven thousand years ago, the people in that presently forgotten area of Central Asia, took part in their own manner in the process of Neolithisation 


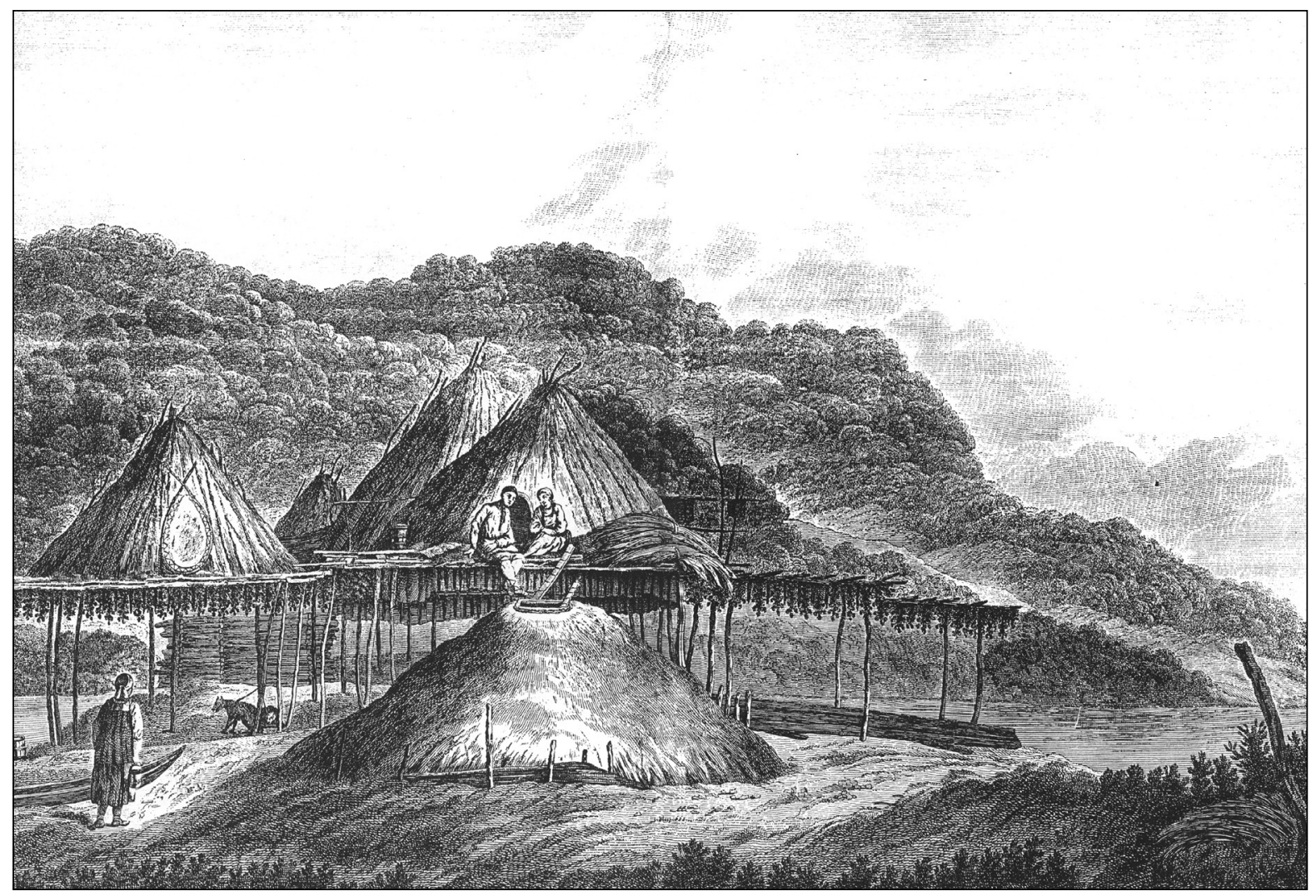

Fig. 16. Village of Kamchatka with a winter semi-subterranean house. The only way of access is via an aperture in the roof (after Cook 1785).

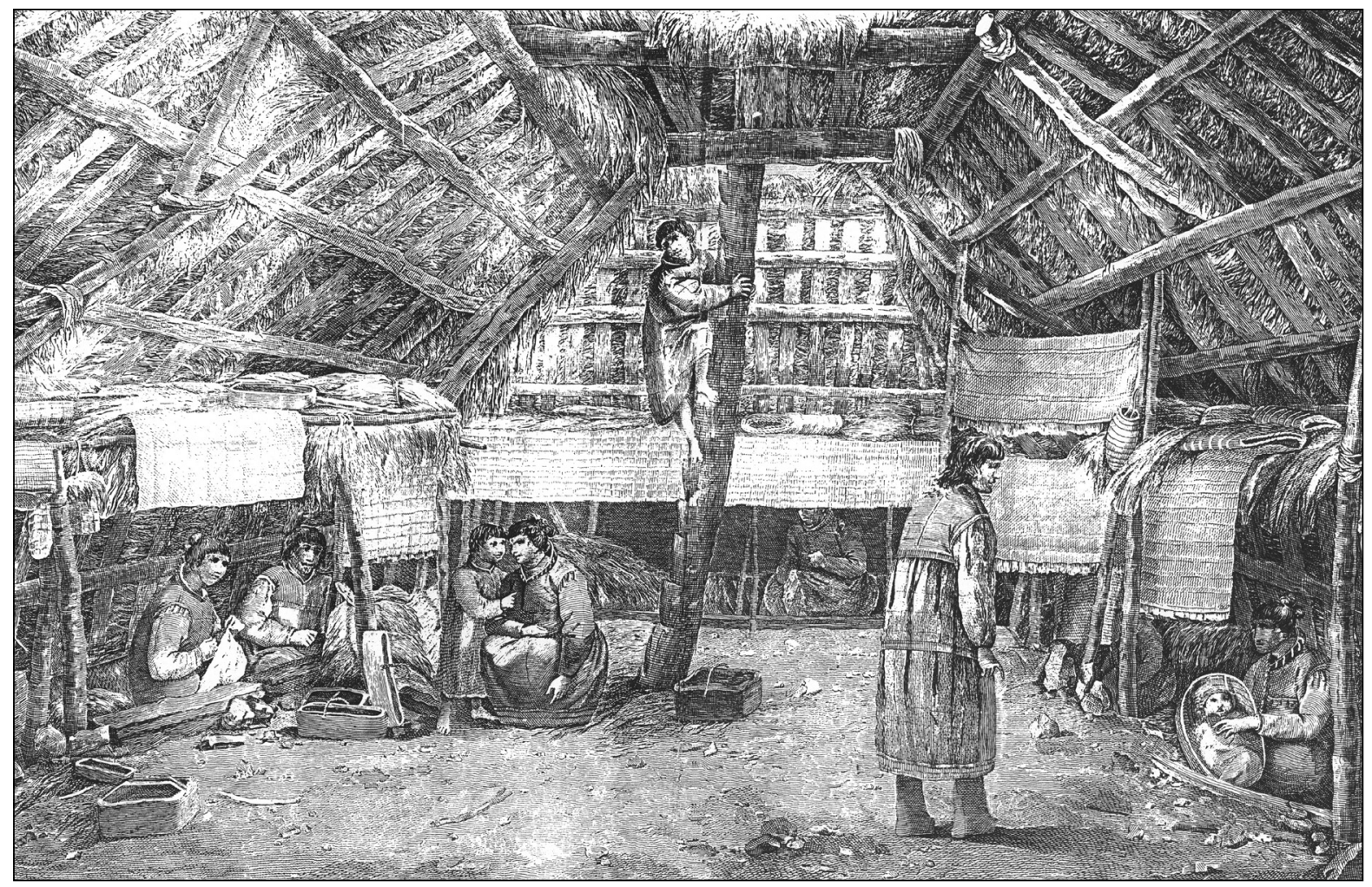

Fig. 17. Inside look of a house from Alaska. The only way of access, using a trunk with incised steps, is also via an aperture in the roof (after Cook 1785). 
that encompassed the whole of Eurasia. Adapting to a very special local environment, they chose an original form of food-producing economy, comparable to the broadly contemporaneous great civilizations of Yangshao and Longshan in China, Jomon in Japan, as well as those of southern Siberia, Kazakhstan, Central and Eastern Europe, and the European early Neolithic complex (exemplified by 'Linear pottery'), which extended from the Carpathian Mountains to Armorica. They were both hunter-gatherers and farmers. At present it is difficult to assess which branch of their economy played a leading role; this remains one of the main objectives of our project; we may only suggest that these branches were mutually complementary. In contrast to their predecessors, they were rather sedentary dwellers than nomads. And they remained so, until the new change of climate and the advance of the steppe made them change their mode of subsistence: they became hunters and, more importantly, stock-breeders once more, who increasingly led herds of goat, sheep, camels, and horses still farther beyond the endless horizon.

\section{REFERENCES}

BERKELEY C. P., NELSON N. C. 1926. Geology and Prehistoric Archaeology of the Gobi Desert. Am. Mus. Novit (New York) 222: 3-18.

CHANG K.-C. 1986. The Archaeology of Ancient China. Yale University Press: Taiwan Edition.

\section{DEREVIANKO A. P. 1970. Novopetrovskaja kul'tura} Srednego Amura. Novosibirsk.

1994. Central and Northern Asia during the Neolithic. In History of Humanity, vol. I: Prehistory and Beginnings of Civilization, edited by S. J. De Laet. Paris, Unesco: 457-467.

DEREVIANKO A. P., DORJ D. 1992. Neolithic Tribes in Northern Parts of Central Asia. In History of Civilizations of Central Asia, vol. I, edited by A. H. Dani, V. M. Masson. Paris, Unesco: 169-189.

DEREVIANKO A. P., OLSEN J. W., TSEVENDORJ D. 1996. Archaeological Studies carried out by the joint Russian-Mongolian-American Expedition in Mongolia in 1995. Novosibirsk.

1998. Archaeological Studies carried out by the joint Russian-Mongolian-American Expedition in Mongolia in 1996. Novosibirsk.

DORJ D. 1969. Neolithic Burials and Dwellings in Eastern Mongolia. Izvestiya Akademii Nauk Mongol'skoy Narodnoy Respubliki: 34-53.

1971. Neolit vostocnoj Mongolii. Ulaan Baatar.

1974. Tamsa-Bulagkaja kul'tura i eë mesto v drevnejshej istorii Tsentral'noj Azii. Rol' kochevîkh na- rodov v Tsivilizatsii Tsentral'noj Azii. Ulaan Baatar: 43-56.

DORJ D., DEREVIANKO A. P. 1970. Novîje materiali dlja izuchenija nêolita Vostochnoj Mongolii. Izvestiya Akademii Nauk Mongol'skoy Narodnoy Respubliki, Ulaan Baatar: 43-56.

FAIRSERVIS W. A. Jr. 1993. Archaeology of the Southern Gobi of Mongolia. Carolina Academic Press. Durham, North Carolina.

JOMON 1998. Jomon. L'art du Japon des Origines. Maison de la Culture du Japon à Paris. Paris.

KIM J. -H. 1978. The Prehistory of Korea. The University Press of Hawaii, Honolulu.

KILUNOVSKAYA M., SEMENOV V. 1995. The Land of the Heart of Asia. St Petersburg, Ego Publishers.

KYZLASOV L. P.1982. Drevnjaja Tuva. Moscow.

MILLEDGE NELSON S. 1993. The Archaeology of Korea. Cambrige University Press.

MILLEDGE NELSON S. 1995. The Archaeology of Northeast China. Beyond the Great Wall. Routledge, London.

NATSAGDORJ S. 1987. Archaeology, Ethnography and Anthropology of Mongolia. Novosibirsk.

NAVAN D. 1975. The Bronze Age in Eastern Mongolia. Ulaan Baator.

NELSON N. C. 1926a. The Dune Dwellers of the Gobi. Natural History 28: 305-308. 
1926b. Prehistoric Archaeology of the Gobi Desert. American Museum Novitates 222: 10-16.

NOVGORODOVA E. A. 1989. Drevniaia Mongolija. Moscow.

OKLADNIKOV A. P. 1968. Istorija Siberi. I. Drevnjaja Sibir'. Léningrad.

1986. Paleolit Mongolii. Novosibirsk.

OKLADNIKOV A. P., DEREVIANKO A. P. 1970. Tamsag-Bulak. Neoliticeskaja kul'tura Vostocnoj Mongolii. Materialî po istorii i filologii Tsentral'noy Azii 5: 3-20.

SEFERIADES M. 1993. The European Neolithisation Process. Poročilo o razskovanju paleolita, neolita in eneolita $v$ Sloveniji 21: 137-162.
1999. A Tamsagbulag, les Premiers Paysans de Mongolie. Archéologia (Dijon) 354: 56- 65.

2000. In the Heart of the Eurasian Steppe: Ancient Hunter-Gatherers, First Sedentary Farmers and Nomad Stock Herders of Mongolia (8000-3000 BC). In C. Renfrew and M. Levine (eds.), Late Prehistoric Exploitation of the Eurasian Steppe. Papers presented for the Symposium to be held 12 Jan-16Jan 2000. The McDonald Institute for Archaeological Research, Cambridge, Vol. III: 107125.

SEFERIADES M., STANKO V. 2000. Simples Gibiers ou Objets de Culte? Les Bisons Préhistoriques d'Anetovka (Ukraine). Archéologia (Dijon) 370: 50-55.

VASILEVSKIJ R. S. 1985. Ancient Cultures of Mongolia. Novosibirsk. 